\title{
SOSIALISASI DAN IMPLEMENTASI RENEWABLE ENERGY DI SMKN 1 CIMAHI
}

\author{
Hartono Budi Santoso ${ }^{1}$, Siti Saodah ${ }^{1}$, Sri Utami ${ }^{1}$, Baisrum ${ }^{2}$ \\ ${ }^{1}$ Teknik Konversi Energi Polban \\ ${ }^{2}$ Teknik Elektro Polban \\ Email: hartono_bs@esi_lab.com
}

\begin{abstract}
Abstrak
Pemerintah menargetkan hingga 2030 akan terpasang 6GWp instalasi pembangkit listrik tenaga surya (PLTS). Semakin meningkatnya penggunaan teknologi panel surya harusnya diimbangi dengan penyiapan tenaga kerja yang memiliki kompetensi memahami karaktristik dan teknik instalasi panel surya. Karena jika tidak maka akan banyak lagi proyek-proyek energi terbarukan yang mangkrak, nantinya hanya akan menjadi proyek mercusuar saja tanpa memberikan manfaat kepada masyarakat sekitar. Guna menyiapkan tenaga kerja yang memiliki kompetensi dibidang tenaga surya maka diperlukan banyak pelatihan dan sosialisasi terkait pemanfaatan teknologi tenaga surya. Beberapa kegiatan terkait penerapan teknologi tenaga surya kepada masyarakat lebih ditujukan pada masyarakat sebagai pengguna suatu peralatan yang menggunakan teknologi tenaga surya. Kegiatan tidak ditujukan untuk menyiapkan masyarakat yang memiliki kemampuan untuk melakukan instalasi system yang menggunakan teknologi tenaga surya. Sehingga pada kegiatan ini akan ditujukan untuk meningkatkan kompetensi masyarakat tentang Teknik instalasi teknologi tenaga surya. Kegiatan pemberdayaan ditujukan pada siswa SMK dengan pertimbangan untuk menambah bekal keahlian, khususnya di bidang tenaga surya, ketika mereka lulus nanti. Hal yang menjadi perhatian dalam melaksanakan kegiatan ini adalah para siswa SMK hanya memiliki bekal pengetahuan tentang kelistrikan akan tetapi tidak memiliki pengetahuan tentang teknologi tenaga surya. Untuk itu metode sosialisasi yang tepat sangat dibutuhkan agar tujuan pemberdayaan para siswa SMK untuk memiliki kompetensi dibidang teknologi tenaga surya dapat tercapai. Melalui metode sosialisasi secara teori di kelas dan praktek langsung pemberdayaan siswa SMK untuk memahami pengetahuan tentang teknologi surya dan teknik instalasi system PLTS berhasil di pahami. Hasil kegiatan sosialisasi menunjukkan terjadi peningkatan pemahaman pada para siswa terjadi kenaikan tingkat pemahaman dari $40 \%$ menjadi $80 \%$
\end{abstract}

Kata kunci: Sosialisasi, tenaga surya, PLTS, SMK

PENDAHULUAN
Saat ini kapasitas terpasang pembangkit listrik tenaga surya (PLTS) di Indonesia 
DIFUSI

Volume 3, No.1 Januari 2020

masih tertinggal dibandingkan dengan beberapa negara di ASEAN seperti Singapura (130 MWp), Malaysia (375 MWp) dan Thailand (2.700 MWp). Pemerintah menargetkan hingga 2030 akan terpasang 6GWp instalasi PLTS [1]. Penerapan teknologi panel surya semakin banyak dilakukan mulai dari sekala kecil seperti untuk lampu jalan hingga skala besar berupa pembangkit listrik tenaga surya (PLTS) dengan kapasitas mencapai 1 MW [2-3]. Guna mendorong penggunaan listrik tenaga surya pemerintahnya mengeluarkan program PLTS Atap. Dimana diharapkan disetiap rumah banyak dipasang system PLTS untuk mengurangi konsumsi energi listrik dari PLN. Apalagi dengan semakin kompetitifnya harga perangkat PLTS diharapkan program PLTS Atap menjadi semakin diminati.

Akan tetapi ada hal lain yang perlu menjadi perhatian, yaitu terkait penyiapan tenaga kerja dibidang tenaga surya. Kementrian Energi dan Sumber Daya Mineral (ESDM) mencatat bahwa 5\% dari 719 pembangkit listrik tenaga mini hidro (PLTMh) dan Pembangkit Listrik Tenaga Surya (PLTS) di beberapa desa mengalami kerusakan, hal ini berdampak pada pasokan listrik di beberapa desa [4-5]. Penyebabnya adalah kurangnya perawatan dari masyarakat terhadap fasilitas pembangkit listrik yang ada. Hal ini selain karena terbatasnya peralatan di daerah dan rendahnya kemampuan keuangan masyarakat juga disebabkan keterbasan pada Sumber Daya Manusia (SDM) yang memiliki pengetahuan dalam pengelolaan sumber daya pembangkit listrik energi terbarukan.
Permasalahan juga terjadi pada implementasi Penerangan Jalan Umum Tenaga Surya (PJUTS), salah satunya di kabupaten Jepara, dimana hampir 90\% PJUTS yang belum lama terpasang mengalami kerusakan. Hal ini dikarenakan oleh banyak hal, mulai dari kesalahan perhitungan kapasitas baterai hingga pemahaman yang salah terkait perawatan PJUTS. Selama ini pemahaman yang diberikan terkait PJUTS adalah bebas perawatan, karena menggunakan tenaga surya, padahal dengan kondisi lingkungan jalanan yang panas dari terik matahari dan debu kendaraan PJUTS perlu dilakukan perawatan rutin [6].

Berangkat dari hal ini, tampak bahwa semakin meningkatnya penggunaan teknologi panel surya harusnya dibarengi dengan penyiapan tenaga kerja yang memiliki kompetensi memahami karaktristik dan teknik instalasi panel surya. Karena jika tidak maka akan banyak lagi proyek-proyek energi terbarukan yang nantinya hanya akan menjadi proyek mercusuar saja tanpa memberikan manfaat kepada masyarakat sekitar. Guna menyiapkan tenaga kerja yang memiliki kompetensi dibidang tenaga surya maka diperlukan banyak pelatihan dan sosialisasi terkait pemanfaatan teknologi tenaga surya.

Beberapa kegiatan sosialisasi telah dilakukan oleh beberapa lembaga, baik dari pemerintah, swasta. Penerapan tenaga surya pada masyarakat salah satunya digunakan untuk penerangan pada lokasi wisata Watu Tekek, di kabupaten kulon progo, yang belum dialiri listrik karena lokasinya yang cukup curam dan medan yang terjal. Melalui kegiatan ini telah dilakukan perancangan dan pemasangan 
fasilitas pembangkit listrik tenaga matahari. Kegiatan ini lebih ditujukan untuk pemberdayaan lokasi wisata tersebut, tidak pada pemberdayaan masyarakatnya terhadap pengetahuan tentang PLTS [7]. Pada kegiatan lain Meita R. dkk melakukan sosialisasi penerapan teknologi tenaga surya untuk memenuhi kebutuhan listrik rumah sederhana di Desa Lahopang Kabupaten Sitaro Provinsi Sulawesi Utara. Pada kegiatan ini dilakukan pemasangan PLTS dan bimbingan teknis tentang pengoperasian PLTS, sehingga diharapkan masyarakat dapat menjaga keberlanjutan operasi PLTS [8].

M. Zainuddin dan M Darmawan melakukan sosialisasi penggunaan tenaga surya sebagai pembangkit listrik untuk menyalakan pompa irigasi di Kelurahan Tanggikiki kabupaten Gorontalo. Penerapan pompa air tenaga surya (PATS) ditujukan untuk memenuhi kebutuhan air irigasi persawahan yang kesulitan air saat kemarau. Selain melakukan instalasi pada kegiatan ini juga dilakukan sosialisasi penggunaan PATS, sehingga diharapkan masyarakat dapat menjaga dan memelihara peralatan PATS [9].

Dari ketiga kegiatan tersebut tampak bahwa sosialisasi terkait teknologi tenaga surya kepada masyarakat lebih ditujukan pada masyarakat sebagai pengguna suatu peralatan yang menggunakan teknologi tenaga surya. Kegiatan tidak ditujukan untuk menyiapkan masyarakat yang memiliki kemampuan untuk melakukan instalasi system yang menggunakan teknologi tenaga surya. Sehingga pada kegiatan ini akan ditujukan untuk meningkatkan kompetensi masyarakat tentang Teknik instalasi teknologi tena- ga surya. Kegiatan pemberdayaan ditujukan pada siswa SMK dengan pertimbangan untuk menambah bekal keahlian, khususnya dibidang tenaga surya, ketika mereka lulus nanti. Hal yang menjadi perhatian dalam melaksanakan kegiatan ini adalah para siswa SMK hanya memiliki bekal pengetahuan tentang kelistrikan akan tetapi tidak memiliki pengetahuan tentang teknologi tenga surya. Untuk itu metode sosialisasi yang tepat sangat dibutuhkan agar tujuan pemberdayaan para siswa SMK untuk memiliki kompetensi dibidang teknologi tenaga surya dapat tercapai. Pada kegiatan ini akan diterapkan metode sosialisasi secara teori di kelas dan praktek langsung, diharapkan pemberdayaan siswa SMK untuk memahami pengetahuan tentang teknologi surya dan teknik instalasi system PLTS berhasil dicapai.

\section{METODE}

Metode yang digunakan pada pengabdian kepada masyarakat di SMKN $1 \mathrm{Ci}$ mahi ini berangkat dari pendekatan hasil analisis situasi yang dijumpai dan disepakati oleh Mitra sebagai bentuk kegiatan yang ditawarkan. Keseluruhan tahapan pelaksanaan kegiatan seperti tampak pada Gambar 1.

\section{Tahapan Kegiatan}

a. Survey

Pada tahap ini tim pengabdian pada masyarakat (P2M) melakukan visitasi ke lapangan, yakni SMKN 1 Cimahi untuk memperoleh informasi mengenai profil sekolah, kondisi lingkungan, ruang kerja dan ruang belajar siswa, data mengenai workshop yang sudah diperoleh oleh sis- 
wa terkait renewable energy. Informasi diperoleh melalui wawancara dengan pihak pengajar, siswa, dan staf sekolah. Dilakukan pula interview mengenai pemaparan yang telah dilakukan, baik oleh pihak internal sekolah maupun pihak eks- ternal, mengenai pengenalan dan pembimbingan terkait energi baru terbarukan. Dari hasil analisis yang diperoleh, maka ditentukan pemilihan tema yang telah dijustifikasi oleh mitra.

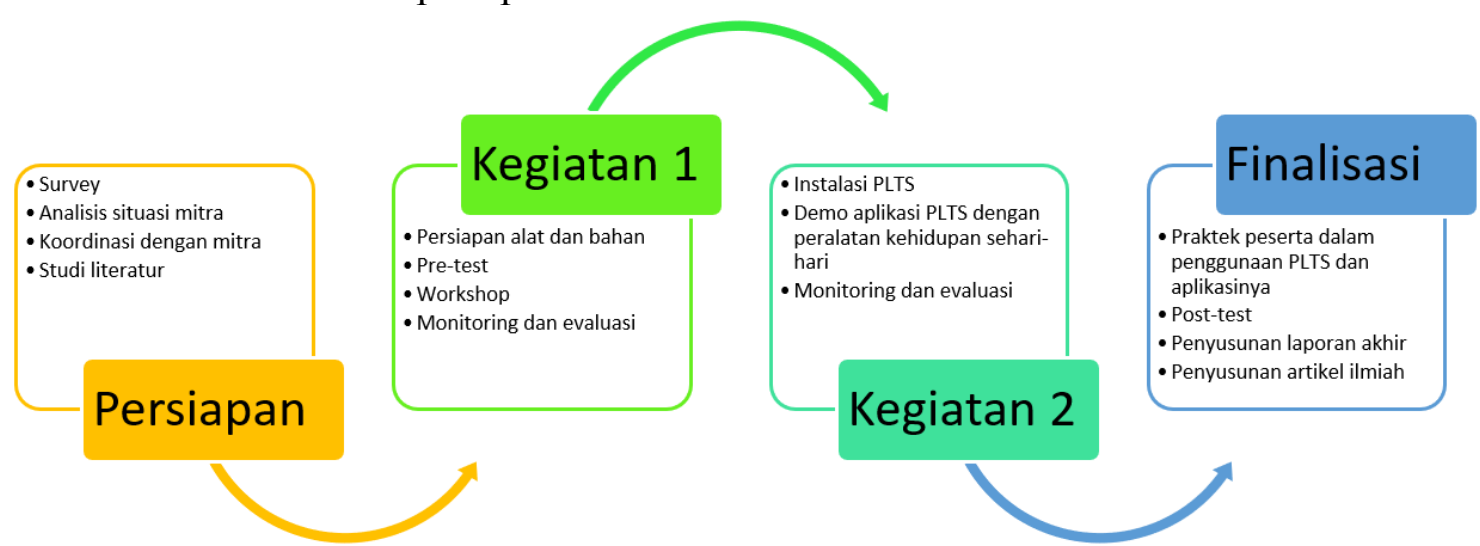

Gambar 1. Metode pelaksanaan kegiatan PKM di SMKN 1 Cimahi

b. Koordinasi dengan mitra

Pada tahap ini hasil justifikasi permasalahan telah disepakati oleh mitra dan perumusan.

c. Penentuan tujuan kegiatan

Dari hal tersebut muncul bentukbentuk kegiatan yang ditawarkan oleh tim pengabdian masyarakat Jurusan Teknik Konversi Energi (JTKE) yaitu pengenalan dan implementasi renewable energy sesuai dengan kebutuhan pelajar SMKN 1 Cimahi.

d. Persiapan alat dan bahan

Dalam hal ini tim P2M JTKE dan mitra saling berkoordinasi mengenai persiapan pelaksanaan kegiatan pengabdian yang berkaitan dengan sarana prasarana dan supporting tools yang dibutuhkan selama kegiatan pengabdian pada masyarakat berlangsung.

e. Pelatihan
Pada tahap ini tim pengabdian pada masyarakat JTKE akan memberikan pengenalan mengenai dasar sumber energi baru terbarukan serta aplikasi sederhananya dalam kehidupan sehari-hari. Hal ini dilakukan terutama untuk memberikan basic knowledge mengenai EBT.

f. Praktek instalasi PLTS

Pada tahap ini diperkenalkan bagaimana cara menggunakan modul PLTS serta contoh aplikasi PLTS sederhana sehingga akan diperoleh pemahaman yang menyeluruh mengenai bagaimana instalasi PLTS serta pengaplikasiannya penggunaannya dalam kehidupan sehari-hari.

g. Monitoring dan evaluasi

Monitoring dan evaluasi yaitu tahap pemantauan dari hasil kegiatan workshop yang telah dilakukan, dimana indikator keberhasilan kerja dapat dilihat dari sejauh mana peserta telah mengetahui dan mema- 
hami Energi Baru Terbaraukan (EBT) serta peggunaannya dan aplikasinya, melalui pre-test dan post-test yang diberikan tim pengabdian pada masyarakat JTKE. Selain itu juga dilakukan interview kepada peserta mengenai pemahaman materi pelatihan yang telah diperoleh.

\section{Profil Calon Mitra}

SMK Negeri 1 Cimahi adalah salah satu Lembaga Pendidikan Menengah Kejuruan di Kota Cimahi, Jawa Barat yang menyelenggarakan Program Pendidikan Kejuruan 4 Tahun, dan merupakan salah satu SMK dari 8 (delapan) SMK Negeri di Indonesia yang memiliki program 4 (empat) Tahun. SMK ini berdiri di atas tanah seluas 3,4 Ha yang pembangunan fisiknya dimulai sejak tahun 1969 . Penerimaan siswa dilakukan sejak tahun 1974 dengan nama awal STM Negeri Pembangunan Bandung dan diresmikan pada 24 Maret 1977. SMKN 1 Cimahi menyandang nama STM Pembangunan sampai tahun 1995/1996, dan menggunakan nama SMK 1 Cimahi sejak tahun 1996/1997 dengan dasar SK Mendikbud No. 036/O/97. Dengan adanya otonomi daerah dan berpisahnya Kota Cimahi dengan Kab. Bandung, maka pada tahun pelajaran 2001/2002 STM Pembangunan Bandung berubah nama menjadi SMK Negeri 1 Kota Cimahi [10].

SMK Negeri 1 Cimahi secara geografis terletak di kawasan Industri, dapat diakses dengan mudah dari berbagai sudut kota Cimahi, baik dari atau ke Kota Bandung, Kabupaten Bandung dan Kota Jakarta. Selain itu posisi SMKN $1 \mathrm{Ci}$ mahi dapat pula dengan diakses oleh in- dustri-industri yang berada di kawasan industri di Jalur Pantura Provinsi Jawa Barat. Sehingga akses yang dapat dilakukan untuk kepentingan akademik baik pembelajaran di sekolah maupun di luar sekolah (Dunia Usaha / Dunia).

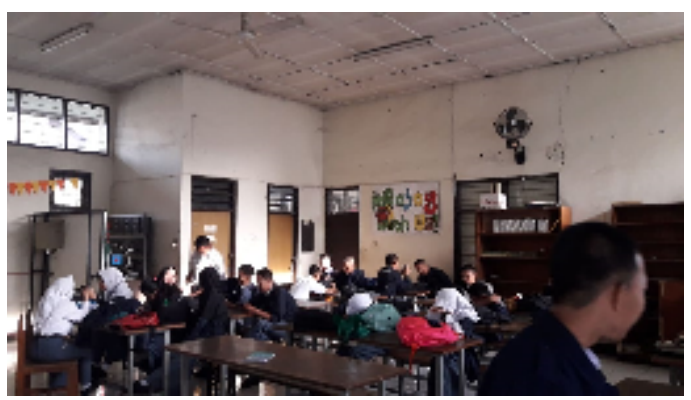

Gambar 2 Suasana belajar di salah satu kelas di SMKN 1 Cimahi

\section{Pembangkit Listrik Tenaga Surya (PLTS)}

Pembangkit listrik tenaga surya (PLTS) adalah system konversi energi dari radiasi matahari menjadi energi listrik menggunakan teknologi panel surya. Listrik yang dihasilkan oleh panel surya selanjutnya dikonversi menjadi tegangan DC dengan nominal tegangan tertentu sesuai dengan beban yang terhubung dengan system PLTS tersebut. Jika akan mensuplai beban dengan tegangan kerja AC maka diperlukan perangkat inverter yang akan merubah daya listrik DC yang dihasilkan panel surya menjadi daya listrik AC. Beberapa system PLTS menggunakan baterai sebagai media penyimpanan daya sehingga pada saat radiasi matahari meredup, PLTS masih dapat menghasilkan daya yang cukup untuk mensuplai beban. Ada juga system PLTS yang terhubung dengan jaringan listrik PLN, pada system ini diperlukan inverter tipe grid tie inverter 
(GTI). Konfigurasi system PLTS seperti tampak pada Gambar 3.

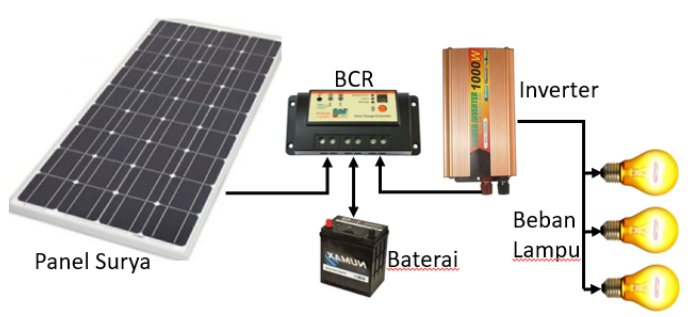

Gambar 3. Konfigurasi PLTS

\section{Laboratorium PLTS Jurusan Teknik Konversi Energi}

Jurusan Teknik Konversi Energi Politeknik Negeri (JTKE) Bandung memiliki fasilitas laboratorium PLTS dengan kapasitas 15KWp. Fasilitas laboratorium ini digunakan untuk menunjang kegiatan praktikum energi terbarukan. Selain PLTS dengan kapasitas besar ada beberapa konfigurasi PLTS dengan kapasitas kecil. Sehingga memungkinkan mahasiswa belajar beberapa tipe konfigurasi system PLTS, seperti Solar home system, PLTS mandiri dan PLTS terhubung jaringan.

\section{HASIL DAN PEMBAHASAN}

Kegiatan dimulai dengan memberikan pre-test terkait pengetahuannya mengenai pembangkit baru terbarukan. Dilanjutkan dengan pemberian materi terkait dengan pengenalan mengenai renewable energy secara umum. Peserta yang mengikuti acara ini sebanyak 20 orang dari kelas 2 SMKN 1 Cimahi Jurusan. Teknik Otomasi Industri dan Proses, mahasiswa jurusan Teknik Konversi Energi yang terlibat sebanyak 12 orang. Pemberian materi sendiri terbagi menjadi dua sesi. Sesi pertama adalah penge- nalan renewable energy secara general dan yang kedua merupakan pengenalan Pembangkit Listrik Tenaga Surya (PLTS). Materi teori dan praktek tentang PLTS yang diberikan meliputi:
a. Pengenalan karakteristik photovoltaic
b. Solar Home System (SHS) DC
c. Solar Home System (SHS) AC
d. Grid Tie Inverter (GTI)

Pengenalan dan implementasi PLTS ini dilakukan di Laboratorium Energi Baru Terbarukan Jurusan Teknik Konversi Energi. Rangkaian kegiatan sosialisasi tentang energi terbarukan ini seperti tampak pada Gambar 4 s.d. 6 .

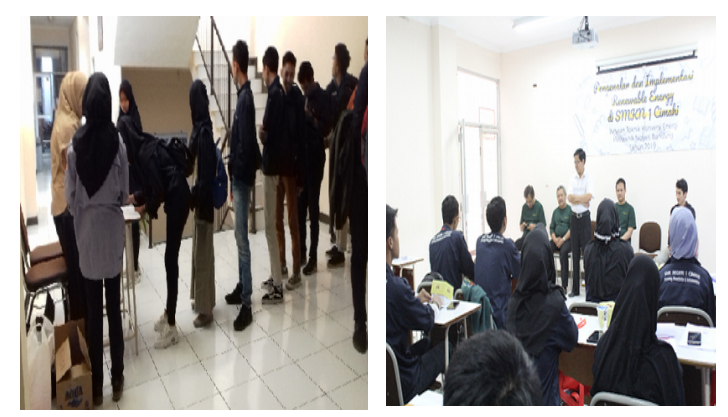

Gambar 4. Rangkaian Kegiatan pendaftaran dan pembukaan

Pada akhir kegiatan diberikan post test untuk melihat tingkat pemahaman dari peserta setelah dilakukan kegiatan pembekalan tentang teknologi tenaga surya. Hasil yang diperoleh berdasarkan kegiatan pre test dan post test menunjukkan adanya peningkatan pengetahuan peserta pelatihan tentang teknologi tenaga surya. Hasil yang terukur merupakan diperoleh dari proses pengajaran yang tidak hanya bersifat satu arah, namun juga secara aktif melibatkan peserta melalui beberapa metode pelatihan, yaitu: 


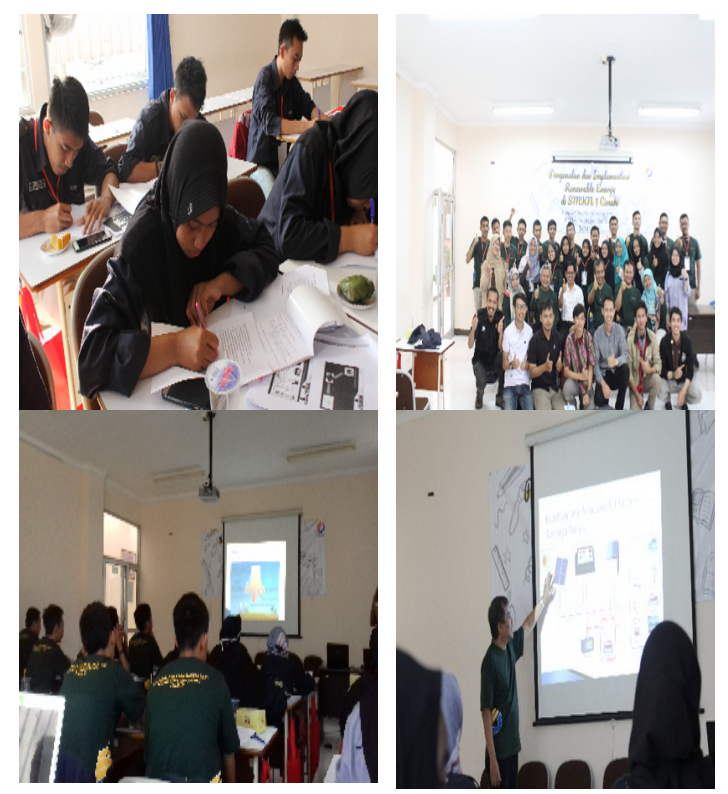

Gambar 5. Kegiatan Penyampaian Materi

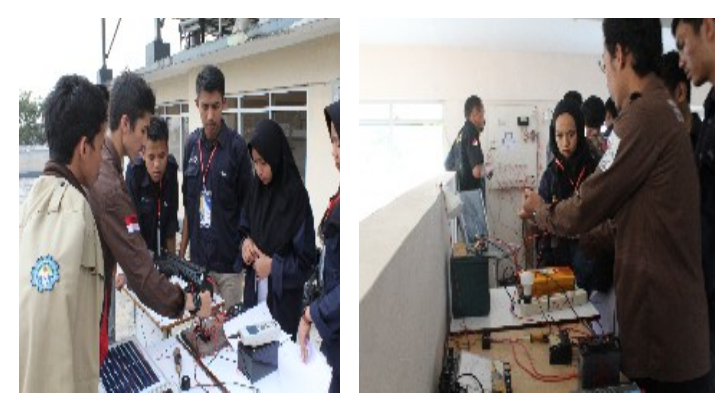

Gambar 6. Photo Bersama dan Praktek PLTS

1. Pengajaran di ruang kelas oleh pelatih menyangkut dasar-dasar sistem PLTS

2. Studi kasus dalam kelompok, menggunakan alat (tools) yang digunakan oleh tim

3. Bermain peran, untuk melatih berpikir kritis dalam melakukan pelatihan

Dalam pelaksanaannya, beberapa peserta menunjukkan antusiasme dan perhatian yang besar terhadap proses pelatihan dan ilmu yang disampaikan. Hal ini me- rupakan aset berharga bagi POLBAN khususnya JTKE.

Pelatihan dilakukan selama satu hari, dengan peserta selalu didampingi oleh instruktur untuk merakit PLTS dan dijelaskan secara terperinci komponenkomponen apa saja yang dibutuhkan dan bagaimana cara kerja dari tiap komponen dan disediakannya juga single line diagram agar mempermudah peserta dalam melakukan perangkaian PLTS.

Sebelum memulai pelatihan TIM melakukan proses evaluasi dasar dengan menyusun soal dasar untuk mengetahui kemampuan peserta pelatihan. Susunan pertanyaan yang digunakan dalam tes adalah sebagai berikut :

Q1. Apa yang dimaksud dengan sumber energi terbarukan

Q2. Apa yang Anda ketahui tentang Pembangkit Listrik Tenaga Surya

Q3. Apa yang Anda ketahui tentang panel surya

Q4. Apa yang Anda ketahui tentang Battery Charge Regulator (BCR)

Q5. Apa yang Anda ketahui tentang inverter

Q6. Apa yang Anda ketahui tentang beban DC dan beban $A C$

Q7. Bagaimana merangkai rangkaian penerangan menggunakan tenaga surya

Q8. Apa yang Anda ketahui tentang baterai

Q9. Bagaimana merangkai baterai pada rangkaian PLTS

Q10. Apa yang Anda ketahui tentang PLTS yang terhubung dengan PLN

Berdasarkan hasil pretest, dapat dilihat peserta yang memiliki tingkat pengetahuan tentang PLTS dan energi terbarukan (Q1-Q3), hampir diatas 50\%, akan tetapi pengetahuan tentang komponenkomponen yang dibutuhkan untuk membangun satu system PLTS dan konfigurasi apa saja yang dapat dibuat dari 
DIFUSI

Volume 3, No.1 Januari 2020

sistem PLTS (Q4 - Q10) peserta ratarata memiliki tingkat pengetahuan seki$\operatorname{tar} 40 \%$, gambar 7. Hal ini dapat dipahami karena disekolah mereka memang tidak dibekali dengan topik tentang PLTS.

Perbandingan Hasil Pre Test dan Post Test berdasarkan Topik Pertanyaan

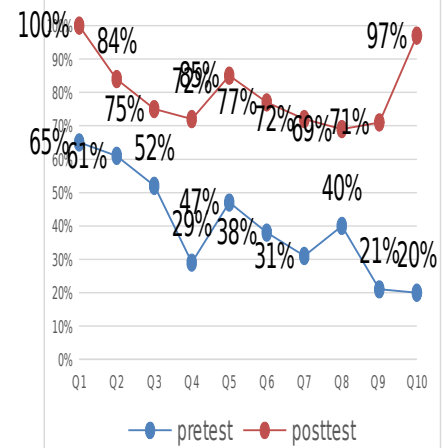

Gambar 7. Grafik Hasil Pretest dan Postest penguasaan materi PLTS

Perbandingan pre test dan post test dari setiap peserta

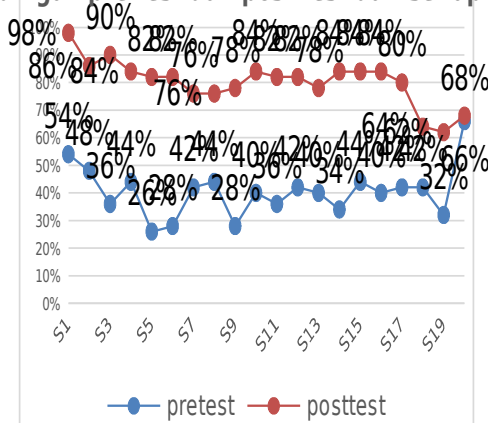

Gambar 8. Grafik Hasil Pretest dan Postest terkait Pengetahuan Peserta tentang PLTS

Pada sesi terakhir setelah peserta mengikuti kegiatan pengajaran dan dilanjutkan dengan kegiatan praktikum tentang topik PLTS, diberikan post test dengan jenis soal yang sama seperti pada saat peserta mau melakukan pelatihan PLTS. Hasil test menunjukkan tingkat pengetahuan tentang PLTS, energi terbarukan dan komponen dari PLTS yang dimiliki peserta mengalami kenaikan rata-rata sekitar $80 \%$, gambar 8 .

Jika dilihat berdasarkan tingkat pemahaman dari masing-masing peserta tampak sebelum dilakukan pengajaran dan kegiatan praktikum, tingkat pemahaman dari setiap peserta rata-rata disekitar angka $40 \%$ Hasil post test menunjukkan, pengetahuan setiap peserta tentang PLTS dan komponennya hampir semuanya memiliki tingkat pengetahuan mencapai rata-rata diatas $80 \%$. Hal ini menunjukkan bahwa dengan metode sosialiasi yang kita berikan, dapat meningkatkan tingkat pengetahuan dari setiap siswa tentang PLTS. Jika dilihat dari peningkatan tingkat pemahaman dari setiap topik yang diberikan pada test, tampak bahwa pemahaman peserta tentang PLTS dapat dihubungkan dengan jaringan cukup tinggi. Hal ini bisa dikarenakan selama ini yang diketahui mereka PLTS bekerja secara stand alone, ternyata PLTS dapat bekerja dengan PLN.

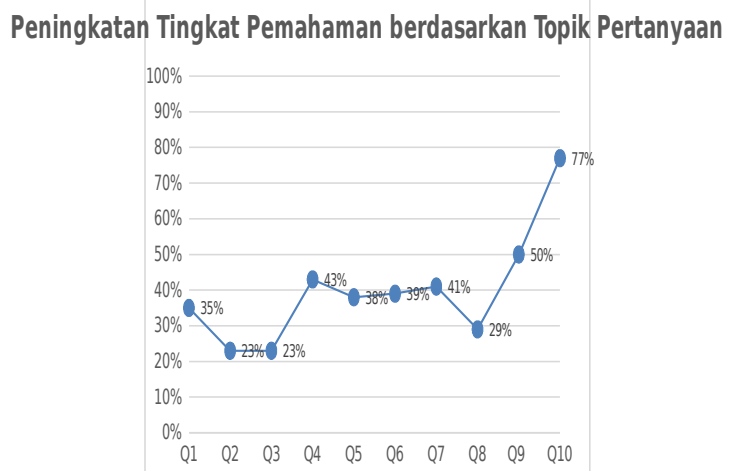

Gambar 1. Grafik Peningkatan Tingkat Pemahaman Terkait Topik PLTS

Berdasarkan hasil test secara keseluruhan tampak bahwa para peserta mengerti tentang pentingnya PLTS tetapi tidak memiliki pengetahuan dasar dan pengalaman yang memadai mengenai sis- 
DIFUSI

Volume 3, No.1 Januari 2020

tem PLTS. Pencapain ini akan menjadi lebih baik seandainya dilakukan untuk waktu yang lebih lama. Agar kegiatan sosialisasi tetap dapat dilakukan di SMK Negeri 1 Cimahi maka dari kegiatan ini juga telah diserahkan satu set PLTS kapasitas $150 \mathrm{Wp}$ untuk penerangan, ke SMK Negeri 1 Cimahi.

\section{KESIMPULAN}

Setelah dilakukan evaluasi melalui post-test dan pre-test, maka peserta dapat memahami komponen apa saja yang dibutuhkan untuk membangun PLTS dan bagaimana merakitnya. Terjadi peningkatan tingkat pengetahuan peserta tentang teknologi tenaga surya. Dari sebelumnya hanya memiliki tingkat pengetahuan rata-rata disekitar $40 \%$ menjadi $80 \%$. Pencapain ini akan menjadi lebih baik seandainya dilakukan untuk waktu yang lebih lama. Agar sosialisasi pengetahuan tentang tenaga surya, selanjutnya dapat dilaksana-kan di SMKN 1 Cimahi maka telah diserah-kan 1 set perangkat PLTS untuk penerangan kapasitas $150 \mathrm{Wp}$.

\section{REFERENSI}

[1] Indonesia, Pemanfaatan Sumber Energi Baru Terbarukan untuk Penyediaan Tenaga Listrik, 2017.
[2] ESDM, Ditjen Energi Baru Terbarukan dan Konservasi Energi.

[3] Indonesia, Peraturan Presiden tentang Kebijakan Energi Nasional Pasal 2(2) b, Vol. PP No. 5, 2006.

[4] Indonesia. (2014a). Pengesahan Statute of The International Renewable Energy Agency

[5] Indonesia. (2014b). Peraturan Pemerintah tentang Kebijakan Energi Nasional, PP No. 79 Pasal 9.f.

[6] M. Azhar, Implementasi Kebijakan Energi Baru dan Energi Terbarukan dalam Rangka Ketahanan Energi Nasional. Adminitrative Law and Governance Journal, 1(4), 15, 2018.

[7] E. L. Utari, L. Listyalina, dan N. Irawati, Aplikasi Teknologi Tepat Guna Melalui Pemanfaatan Energi Terbarukan Untuk Penerangan Dan Pengembangan Wisata Watu Tekek Kulonprogo, Dharma karya: Jurnal Aplikasi Ipteks untuk Masyarakat Vol. 8, No. 3, pp. 140 - 144, 2019

[8] M. Rumbayan, S. Tangkuman, dan S. R. U. Sompie, Penerapan Pembangkit Listrik Tenaga Surya Skala Rumah Sederhana Di Desa Lahopang Kabupaten Sitaro Provinsi Sulawesi Utara, Ethos (Jurnal Penelitian dan Pengabdian Masyarakat), Vol 6, No.1, pp. 52-61, 2018.

[9] M. Zainuddin dan M. Darmawan, Pemanfaatan Pompa Air Tenaga Surya (Pats) Untuk Irigasi Lahan Sawah Di Kelurahan Tanggikiki Kota Gorontalo, Majalah Aplikasi Ipteks NGAYAH Volume 8, Nomor 2, pp. 151-158, 2017

[10] SMKN 1, C. Sejarah Singkat, 2019. 